\title{
Palladium-Catalyzed Carbofluoroalkylation
}

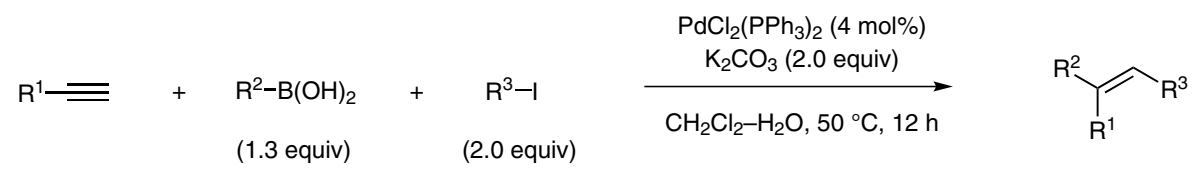

\section{Key words}

palladium

stereoselective reaction

alkynes

Selected examples:<smiles>FC(F)(F)C=C(c1ccc(C(F)(F)F)cc1)C(F)(F)F</smiles>

$75 \%$ yield<smiles>COc1ccc(C(=CC(F)(F)F)c2ccc(C(C)(C)C)cc2)cc1</smiles>

$81 \%$ yield<smiles>COc1ccccc1/C(=C\C(F)(F)F)c1ccccc1</smiles>

$79 \%$ yield<smiles>CC(C)(C)c1ccc(C(=CC(F)(F)F)c2ccccc2F)cc1</smiles>

$70 \%$ yield<smiles>Fc1ccccc1/C(=C\C(F)(F)F)c1ccccc1</smiles>

$78 \%$ yield<smiles>Cc1cccc(C(=CC(F)(F)F)c2ccc(C(C)(C)C)cc2)c1</smiles>

$83 \%$ yield
Significance: The authors describe a palladiumcatalyzed three-component reaction involving terminal alkynes, boronic acids, and perfluoroalkyl iodides, leading to the desired products in a highly regio- and stereocontrolled manner.
Comment: From a mechanistic point of view, the simultaneous addition of both aryl and $\mathrm{C}_{n} \mathrm{~F}_{m}$ groups across the triple bond in a radical-mediated process is proposed. 